(C) The Author(s), 2021. Published by Cambridge University Press for the Arizona Board of Regents on behalf of the University of Arizona. This is an Open Access article, distributed under the terms of the Creative Commons Attribution licence (https://creativecommons.org/licenses/by/4.0/), which permits unrestricted re-use, distribution, and reproduction in any medium, provided the original work is properly cited.

\title{
EARLY AND MIDDLE BRONZE AGE CHRONOLOGY OF THE CARPATHIAN BASIN REVISITED: QUESTIONS ANSWERED OR PERSISTENT CHALLENGES?
}

\author{
Robert Staniuk* (i) \\ Institut für Ur- und Frühgeschichte, Christian-Albrechts-Universität zu Kiel, Johanna-Mestorf-Straße 2-6, R. 24, \\ 24118 Kiel, Germany
}

\begin{abstract}
The Early and Middle Bronze Age in the Carpathian Basin is often viewed as a long period of transition from a dispersed form of land occupation to one of increasing aggregation, ultimately resulting in the formation of tell settlements and large cemeteries. This developmental trajectory remains a legacy of early 20 th century archaeology, where the similarity of material culture recovered from cemeteries and settlements was used to develop a multi-linear scheme of progression of regional chronologies tied to specific archaeological cultures. While typologically conclusive, the recent increase in the availability of radiocarbon determinations suggests that these sequences represent a priori interpretation of social development rather than empirically verified observations. In order to do so, it is necessary to re-evaluate the existing dataset in order to determine whether the formation of tells was a chronologically contemporary development and whether the regional chronological sequences are supported by independent dating.
\end{abstract}

KEYWORDS: Bronze Age, Carpathian Basin, legacy data, radiocarbon dating, settlement archaeology.

\section{INTRODUCTION}

The Carpathian Basin in the Bronze Age is generally characterized as a period of cyclical shifts of population aggregation and dispersion between approx. 2700/2500 and 900/750 BC (Visy 2003; Marková and Ilon 2013). Historically, researchers paid most attention to the Middle Bronze Age (approx. 2000/1900-1600/1450 BC), when multi-layered settlements become one of the primary forms of land occupation, marking the peak in human activities in the region (Gogâltan 1999, 2017; Kienlin 2015; Staniuk et al. 2020). The second most intensively explored part of the Bronze Age sequence is the Late Bronze Age (1600/ 1450-900/750 BC), when large cemeteries linked to the Urnfield phenomenon became widespread (Przybyła 2009; Kalicz-Schreiber 2010). While these two periods are relatively well-defined due to the abundance of archaeological finds, the periods leading up to their formation remain enigmatic (Bóna 1963; Kulcsár 2009; Vicze et al. 2013).

Until recently, the theoretical basis for the archaeological sequence of the Carpathian Basin has been the assumption that changes in material culture correspond to the arrival of distinct ethnic groups (Kalicz 1968; Bóna 1975; Kovács 1977). This axiom had two consequences for the interpretation of regional and site-specific trajectories. On a regional level, it led to complex periodization schemes with trajectories explained by migrations and development of the aforementioned groups (Kalicz 1982; Bóna 1992). On a site-specific level, the connection of material culture with specific groups lead to interpretation of changes in ceramic inventories in settlement layers as indicators of population changes (Máthé 1992; Poroszlai 1992; Stanczik and Tárnoki 1992). Methodologically, the study of material culture changes was conducted on the basis of implicitly defined types of vessels or metal objects with changes following the trajectory of increasing elaboration

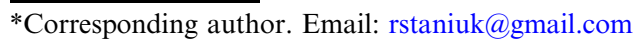


followed by decreasing frequencies in the archaeological record (Vicze 2011; Gömöri et al. 2018). Applied primarily to burial finds, this chronological model proved challenging to implement for settlement finds, where the frequency of intact vessels is substantially lower (Máthé 1984; Michelaki 2008; Staniuk 2020). Despite these empirical obstacles, the trajectories developed on the basis of cemetery finds were rigorously applied to settlement materials, equalizing the chronological positioning of cemeteries and settlements alike.

The increasing presence of radiocarbon dating was initiated in the 1990s with the first dating programs providing an independent way of testing the developmental sequences by positioning them in real time (O'Shea 1992; Raczky et al. 1992; Forenbaher 1993; Barta 2001). Focusing on tell settlements, these first ${ }^{14} \mathrm{C}$-dating programs showed the high degree of contemporaneity of Middle Bronze Age sites. However, a larger number of sites and contexts have been dated since the 1990s, indicating possible differences in chronological positions of previously, contemporaneously considered cemeteries and settlements (Duffy et al. 2019; O'Shea et al. 2019). Rather than stimulating a discussion towards re-evaluation of the existing schemes and concepts, the possibility of synchronizing phenomena across Europe lead to a consolidation of the existing schemes in order to enable narrative-driven investigations of social processes taking place across Europe (Kristiansen and Larsson 2005; Earle and Kristiansen 2010; Fischl et al. 2015). While the reliance on radiocarbon dating was generally embraced by researchers focusing on the Early and Middle Bronze Age, Late Bronze Age contexts remain dated primarily on the basis of typochronology. Therefore, if a radiocarbon-based model of the Carpathian Basin is to be currently provided, it has to be restricted to the Early and Middle Bronze Age sequence.

The shift towards radiocarbon dating allows the reformulation of old research questions and moving away from synchronizing artifact assemblages towards understanding regional developments. This in turn provides the possibility of developing new chronological perspectives on social development and comparative analysis of their compatibility with the existing narratives. To this end, it is necessary to evaluate the existing record of ${ }^{14} \mathrm{C}$ determinations in order to identify the most informative datasets and provide a general perspective on the available data.

This paper collects and investigates the existing dataset of the radiocarbon dates for the Early and Middle Bronze Age Carpathian Basin in order to answer the following questions:

(1) Was the emergence of tell settlements contemporary across different regions?

(2) What is the temporal relationship between burial contexts and settlements in the different regions?

The collected dataset is evaluated in terms of spatial distribution of determinations, their contextual information, and the standard deviation of measurements in order to propose the most reliable dataset for the study. Kernel Density Estimation plots (Bronk Ramsey 2017) are then used to recognize the chronological dynamics between regions and the links between settlements and burials. Finally, the specific trajectories of sites are considered in order to investigate the radiocarbon-based dynamics of human activity in the Carpathian Basin. The results are then evaluated from the perspective of the existing macro- and regional narratives in order to determine whether the existing models of cultural development are supported by the radiocarbon dating. 


\section{MATERIALS AND METHODS}

Table 1 contains the collected radiocarbon dates attributed to the area of study. Site selection was conducted on the basis of general chronological attribution (Early Bronze Age, Middle Bronze Age) or explicit reference to an archaeological unit which could be positioned between the Early and Middle Bronze Age. In total, 496 radiocarbon dates published between 1969 and 2020, originating from 90 sites were included in the study (Supplementary Materials 1 and 2). One date from the settlement of Nižná Myšl'a has been reported but no raw data has been published, therefore effectively reducing the number of dates which can be used to 495 .

Geographically the dataset represents a collection of radiocarbon dates from Hungary, Poland, Romania, Serbia, and Slovakia. Sites included in the study are settlements (flat, multi-layered, and fortified sites), possible settlements (cases where site classification was provided without contextual specification of the dated sample), cemeteries, graves and a single date from an occupied cave. Although outside of the Carpathian Basin, the contexts dated in southern Poland correspond to the cultural determinations developed for the Carpathian Basin in terms of settlement structure and typology. The majority of the available determinations originate from settlements (319, including a single date from an occupied cave), while the burial dataset is represented by 173 determinations. In addition, 9 burials were dated twice, which lowers the number of dated burials to 164 . In 3 instances it was impossible to determine the dated context.

The contextual information represents the data reported in the publications presenting the radiocarbon dating and is made up of a heterogeneous set of investigation-specific coding of archaeological contexts and descriptive reports on the features. In the majority of instances, it was impossible to determine whether the dated contexts can be attributed to any site-specific stratigraphic or typological sequences, which could be used for Bayesian modeling. In addition, the information about the isotopic values of $\delta^{13} \mathrm{C}$ were almost never reported, therefore they were not included in the dataset.

The collected data comprises of a wide spectrum of dated materials, ranging from animal bones to charcoal, human bones, and wood samples. In many instances the determination of faunal and floral taxa was not available; in instances where such information was provided, there was no information on how the determinations were made. Datings coming from unknown/ unspecified materials were also included in the study since they are often used in discussions of regional studies (Duffy et al. 2019).

The dataset was analyzed in terms of the spatial distribution of the radiocarbon determinations in order to identify potential groups. Based on the existing cultural schemes and general spatial characteristics, the investigated sites were divided into 6 groups: Banat $(n=74)$, Carpathians $(n=89)$, Csepel $(n=22)$, Danube-Tisza Interfluve $(n=89)$, Transdanubia $(n=95)$, Transtisza $(n=127)$; named after large geographic regions separated by watercourses or mountain ranges (Figure 1). Independently, a cluster analysis of geographic coordinates using the Ward method displayed that the cut-off at six groups corresponded well with the distinguished groups, apart from the Csepel group. In this case the earlier chronology of the dated contexts, as well as the unique landscape form, i.e. an island was considered as a key factor for why this regional group should remain separate in the following analysis (Patay 2013; Endrődi and Reményi 2016; Czene 2017). 
Table 1 Table of sites and their classification in this study.

\begin{tabular}{|c|c|c|c|c|c|}
\hline $\begin{array}{l}\text { Map } \\
\text { ID }\end{array}$ & Name & Regional group & Reported context & $\begin{array}{l}\text { No. of } \\
{ }^{14} \mathrm{C} \\
\text { datings }\end{array}$ & References \\
\hline 1 & Albertfalva & Transdanubia & $\begin{array}{l}\text { Burial feature; settlement } \\
\text { feature }\end{array}$ & 11 & cf. Supplementary Materials 1 \\
\hline 2 & Apc-Berekalya & $\begin{array}{l}\text { Danube-Tisza } \\
\text { Interfluve }\end{array}$ & Unknown/uncertain & 1 & cf. Supplementary Materials 1 \\
\hline 3 & Bakonszeg-Kádárdomb & Transtisza & Unknown/uncertain & 1 & cf. Supplementary Materials 1 \\
\hline 6 & Balatonőszöd-Temetői dûlő & Transdanubia & Settlement feature & 1 & cf. Supplementary Materials 1 \\
\hline 7 & Baracs & Transdanubia & Settlement feature & 1 & cf. Supplementary Materials 1 \\
\hline 8 & Battonya-Laposéri csatorna & Banat & Unknown/uncertain & 1 & cf. Supplementary Materials 1 \\
\hline 9 & $\begin{array}{l}\text { Battonya-Vörös Október } \\
\text { MTSZ }\end{array}$ & Banat & Burial feature & 16 & cf. Supplementary Materials 1 \\
\hline 10 & Békés-Várserdő & Transtisza & Unknown/uncertain & 1 & cf. Supplementary Materials 1 \\
\hline 14 & Bölcske-Vörösgyír & Transdanubia & Unknown/uncertain & 5 & cf. Supplementary Materials 1 \\
\hline 15 & Bonyhád & Transdanubia & Burial feature & 1 & cf. Supplementary Materials 1 \\
\hline 16 & Bonyhád-Biogas factory & Transdanubia & Burial feature & 7 & cf. Supplementary Materials 1 \\
\hline 17 & Brzezówka 10 & Carpathians & Settlement feature & 8 & cf. Supplementary Materials 1 \\
\hline 18 & Bučany & Carpathians & Settlement feature & 1 & cf. Supplementary Materials 1 \\
\hline 19 & $\begin{array}{l}\text { Budakalász-Csajerszke/M0 } \\
\text { Site } 11\end{array}$ & Transdanubia & Burial feature & 1 & cf. Supplementary Materials 1 \\
\hline 20 & $\begin{array}{l}\text { Budakalász-Csajerszke/M0 } \\
\text { Site } 12\end{array}$ & Transdanubia & Burial feature & 9 & cf. Supplementary Materials 1 \\
\hline 21 & Budapest-Békásmegyer & Transdanubia & Burial feature & 7 & cf. Supplementary Materials 1 \\
\hline 22 & Csepel & Csepel & Unknown/uncertain & 9 & cf. Supplementary Materials 1 \\
\hline
\end{tabular}




\begin{tabular}{|c|c|c|c|c|c|}
\hline $\begin{array}{l}\text { Map } \\
\text { ID }\end{array}$ & Name & Regional group & Reported context & $\begin{array}{l}\text { No. of } \\
{ }^{14} \mathrm{C} \\
\text { datings }\end{array}$ & References \\
\hline 23 & Csepel-Háros & Csepel & Unknown/uncertain & 1 & cf. Supplementary Materials 1 \\
\hline 24 & Csepel-Hollandi ut & Csepel & Unknown/uncertain & 1 & cf. Supplementary Materials 1 \\
\hline 25 & Domony & $\begin{array}{l}\text { Danube-Tisza } \\
\text { Interfluve }\end{array}$ & Unknown/uncertain & 1 & cf. Supplementary Materials 1 \\
\hline 26 & Dunakeszi-Székesdúlő & $\begin{array}{l}\text { Danube-Tisza } \\
\text { Interfluve }\end{array}$ & Burial feature & 1 & cf. Supplementary Materials 1 \\
\hline 27 & $\begin{array}{l}\text { Dunaújváros- } \\
\text { Kosziderpadlás }\end{array}$ & Transdanubia & $\begin{array}{l}\text { Settlement feature; } \\
\text { unknown/uncertain }\end{array}$ & 2 & cf. Supplementary Materials 1 \\
\hline 28 & Emőd-Nagyhalom & Transtisza & Coring & 20 & cf. Supplementary Materials 1 \\
\hline 29 & Erd & Transdanubia & Unknown/uncertain & 9 & cf. Supplementary Materials 1 \\
\hline 30 & Esztár & Transtisza & Unknown/uncertain & 1 & cf. Supplementary Materials 1 \\
\hline 31 & Foeni Gaz & Banat & Settlement feature & 2 & cf. Supplementary Materials 1 \\
\hline 32 & Füzesabony-Pusztaszikszó & $\begin{array}{l}\text { Danube-Tisza } \\
\text { Interfluve }\end{array}$ & Burial feature & 1 & cf. Supplementary Materials 1 \\
\hline 33 & Füzesabony-Öregdomb & $\begin{array}{l}\text { Danube-Tisza } \\
\text { Interfluve }\end{array}$ & $\begin{array}{l}\text { Settlement feature; } \\
\text { Unknown/uncertain }\end{array}$ & 9 & cf. Supplementary Materials 1 \\
\hline 34 & Gáborján-Csapszékpart & Transtisza & Unknown/uncertain & 3 & cf. Supplementary Materials 1 \\
\hline 35 & Gánovce & Carpathians & $\begin{array}{l}\text { Settlement feature; } \\
\text { unknown/uncertain }\end{array}$ & 4 & cf. Supplementary Materials 1 \\
\hline 36 & Gelej-Kanális-dúlő & Transtisza & Burial feature & 1 & cf. Supplementary Materials 1 \\
\hline 37 & $\begin{array}{l}\text { Györ-Ménföcsanak-Széles- } \\
\text { földek }\end{array}$ & Transdanubia & Burial feature & 1 & cf. Supplementary Materials 1 \\
\hline 38 & Hoste & Carpathians & Settlement feature & 3 & cf. Supplementary Materials 1 \\
\hline 39 & Jánoshida-Berek & $\begin{array}{l}\text { Danube-Tisza } \\
\text { Interfluve }\end{array}$ & Burial feature & 1 & cf. Supplementary Materials 1 \\
\hline 40 & Jászdózsa-Kápolnahalom & $\begin{array}{l}\text { Danube-Tisza } \\
\text { Interfluve }\end{array}$ & Unknown/uncertain & 14 & cf. Supplementary Materials 1 \\
\hline
\end{tabular}




\begin{tabular}{|c|c|c|c|c|c|}
\hline $\begin{array}{l}\text { Map } \\
\text { ID }\end{array}$ & Name & Regional group & Reported context & $\begin{array}{l}\text { No. of } \\
{ }^{14} \mathrm{C} \\
\text { datings }\end{array}$ & References \\
\hline 41 & Jelšovce & Carpathians & Burial feature & 14 & cf. Supplementary Materials 1 \\
\hline 42 & Kakucs-Balla-domb & $\begin{array}{l}\text { Danube-Tisza } \\
\text { Interfluve }\end{array}$ & $\begin{array}{l}\text { Burial feature; settlement } \\
\text { feature }\end{array}$ & 10 & cf. Supplementary Materials 1 \\
\hline 43 & Kakucs-Turján & $\begin{array}{l}\text { Danube-Tisza } \\
\text { Interfluve }\end{array}$ & Settlement feature & 12 & cf. Supplementary Materials 1 \\
\hline 44 & Kaposvár-Road 61, Site 12 & Transdanubia & Burial feature & 1 & cf. Supplementary Materials 1 \\
\hline 45 & Kelebia & $\begin{array}{l}\text { Danube-Tisza } \\
\text { Interfluve }\end{array}$ & Burial feature & 1 & cf. Supplementary Materials 1 \\
\hline 46 & $\begin{array}{l}\text { Kiskundorozsma- } \\
\text { Hosszúhát halom }\end{array}$ & $\begin{array}{l}\text { Danube-Tisza } \\
\text { Interfluve }\end{array}$ & Burial feature & 4 & cf. Supplementary Materials 1 \\
\hline 47 & Kiszombor-Új-Élet & Banat & Settlement feature & 7 & cf. Supplementary Materials 1 \\
\hline 48 & Klárafalva-Hajdova & Banat & $\begin{array}{l}\text { Settlement feature; } \\
\text { Unknown/uncertain }\end{array}$ & 13 & cf. Supplementary Materials 1 \\
\hline 49 & Kompolt-Kigyoser & $\begin{array}{l}\text { Danube-Tisza } \\
\text { Interfluve }\end{array}$ & Unknown/uncertain & 1 & cf. Supplementary Materials 1 \\
\hline 50 & Ludas-Varjú-dúlő & $\begin{array}{l}\text { Danube-Tisza } \\
\text { Interfluve }\end{array}$ & Unknown/uncertain & 1 & cf. Supplementary Materials 1 \\
\hline 51 & Makó, Dáli-ugar & Transtisza & Settlement feature & 3 & cf. Supplementary Materials 1 \\
\hline 52 & Maszkowice & Carpathians & Settlement feature & 18 & cf. Supplementary Materials 1 \\
\hline 53 & Mende-Leányvár & $\begin{array}{l}\text { Danube-Tisza } \\
\text { Interfluve }\end{array}$ & Unknown/uncertain & 1 & cf. Supplementary Materials 1 \\
\hline 54 & Mezőcsát-Laposhalom & Transtisza & Coring & 2 & cf. Supplementary Materials 1 \\
\hline 55 & Mokrin & Banat & Burial feature & 6 & cf. Supplementary Materials 1 \\
\hline 56 & Nagyárpád & Transdanubia & Unknown/uncertain & 2 & cf. Supplementary Materials 1 \\
\hline 57 & Nagycenk-Lapos-rét & Transdanubia & Burial feature & 3 & cf. Supplementary Materials 1 \\
\hline 58 & Nagyrozvágy-Pap-domb & Transtisza & Settlement feature & 3 & cf. Supplementary Materials 1 \\
\hline
\end{tabular}




\begin{tabular}{|c|c|c|c|c|c|}
\hline $\begin{array}{l}\text { Map } \\
\text { ID }\end{array}$ & Name & Regional group & Reported context & $\begin{array}{c}\text { No. of } \\
{ }^{14} \mathrm{C} \\
\text { datings }\end{array}$ & References \\
\hline 59 & Nižná Myšl'a & Carpathians & $\begin{array}{l}\text { Burial feature; settlement } \\
\text { feature; unknown/ } \\
\text { uncertain }\end{array}$ & 7 & cf. Supplementary Materials 1 \\
\hline 60 & Nitriansky Hrádok & Western Carpathians & Settlement feature & 1 & cf. Supplementary Materials 1 \\
\hline 61 & Ostojićevo-Stari Vinogradi & Banat & Burial feature & 11 & cf. Supplementary Materials 1 \\
\hline 62 & Pecica "Şanţul Mare" & Transtisza & $\begin{array}{l}\text { Coring; settlement feature; } \\
\text { uknown/uncertain }\end{array}$ & 20 & cf. Supplementary Materials 1 \\
\hline 63 & Polgár-Homok-dúlő & Transtisza & Burial feature & 1 & cf. Supplementary Materials 1 \\
\hline 64 & Polgár-Kenderföld & Transtisza & Unknown/uncertain & 6 & cf. Supplementary Materials 1 \\
\hline 65 & Rabe-Anka Siget & Banat & Coring & 4 & cf. Supplementary Materials 1 \\
\hline 66 & Radzovce & Carpathians & Burial feature & 3 & cf. Supplementary Materials 1 \\
\hline 67 & Rétközberencs-Paramdomb & Transtisza & Unknown/uncertain & 1 & cf. Supplementary Materials 1 \\
\hline 68 & Rozhanovce & Carpathians & Unknown/uncertain & 1 & cf. Supplementary Materials 1 \\
\hline 69 & Sándorfalva-Eperjes & $\begin{array}{l}\text { Danube-Tisza } \\
\text { Interfluve }\end{array}$ & Burial feature & 1 & cf. Supplementary Materials 1 \\
\hline 70 & Sarkad-Vár-tábla & Transtisza & Coring & 5 & cf. Supplementary Materials 1 \\
\hline 71 & Semlac-Livada lui Onea & Transtisza & Coring & 4 & cf. Supplementary Materials 1 \\
\hline 72 & Szakáld & Transtisza & Coring & 1 & cf. Supplementary Materials 1 \\
\hline 73 & Szava & Transdanubia & Unknown/uncertain & 1 & cf. Supplementary Materials 1 \\
\hline 74 & Százhalombatta-Földvár & Transdanubia & Unknown/uncertain & 21 & cf. Supplementary Materials 1 \\
\hline 75 & Szeghalom-Környe & Transtisza & Unknown/uncertain & 1 & cf. Supplementary Materials 1 \\
\hline 76 & $\begin{array}{l}\text { Szentgál-Mecsekhegy, } \\
\text { Kőlik-barlang }\end{array}$ & Transdanubia & Settlement feature & 1 & cf. Supplementary Materials 1 \\
\hline 77 & Szigetcsép & Csepel & Unknown/uncertain & 2 & cf. Supplementary Materials 1 \\
\hline 78 & $\begin{array}{l}\text { Szigetszentmiklós-Felső } \\
\text { Ürge-hegyi dúlő }\end{array}$ & Csepel & Burial feature & 9 & cf. Supplementary Materials 1 \\
\hline 79 & Szőreg-C & Banat & Burial feature & 14 & cf. Supplementary Materials 1 \\
\hline
\end{tabular}




\begin{tabular}{|c|c|c|c|c|c|}
\hline $\begin{array}{l}\text { Map } \\
\text { ID }\end{array}$ & Name & Regional group & Reported context & $\begin{array}{l}\text { No. of } \\
{ }^{14} \mathrm{C} \\
\text { datings }\end{array}$ & References \\
\hline 80 & Tarhos 26 & Transtisza & Settlement feature & 3 & cf. Supplementary Materials 1 \\
\hline 81 & $\begin{array}{l}\text { Toboliu Dâmbu } \\
\text { Zănăcanului }\end{array}$ & Transtisza & Unknown/uncertain & 4 & cf. Supplementary Materials 1 \\
\hline 82 & $\begin{array}{l}\text { Törökszentmiklós- } \\
\text { Terehalom }\end{array}$ & Transtisza & Settlement feature & 2 & cf. Supplementary Materials 1 \\
\hline 83 & Tószeg-Laposhalom & Transtisza & Unknown/uncertain & 6 & cf. Supplementary Materials 1 \\
\hline 84 & Tápé-Széntéglaégeto & $\begin{array}{l}\text { Danube-Tisza } \\
\text { Interfluve }\end{array}$ & Burial feature & 18 & cf. Supplementary Materials 1 \\
\hline 85 & Üllő-Site 5 & $\begin{array}{l}\text { Danube-Tisza } \\
\text { Interfluve }\end{array}$ & Settlement feature & 2 & cf. Supplementary Materials 1 \\
\hline 86 & Včelince & Carpathians & Settlement feature & 5 & cf. Supplementary Materials 1 \\
\hline 87 & Vésztő-Mágor & Transtisza & Unknown/uncertain & 3 & cf. Supplementary Materials 1 \\
\hline 88 & Vráble "Fidvár" & Carpathians & Coring; settlement feature & 24 & cf. Supplementary Materials 1 \\
\hline 89 & Vörs-Máriaaszonysziget & Transdanubia & Settlement feature & 5 & cf. Supplementary Materials 1 \\
\hline 90 & Zsennye-Kavicsbánya & Transdanubia & Burial feature & 4 & cf. Supplementary Materials 1 \\
\hline
\end{tabular}




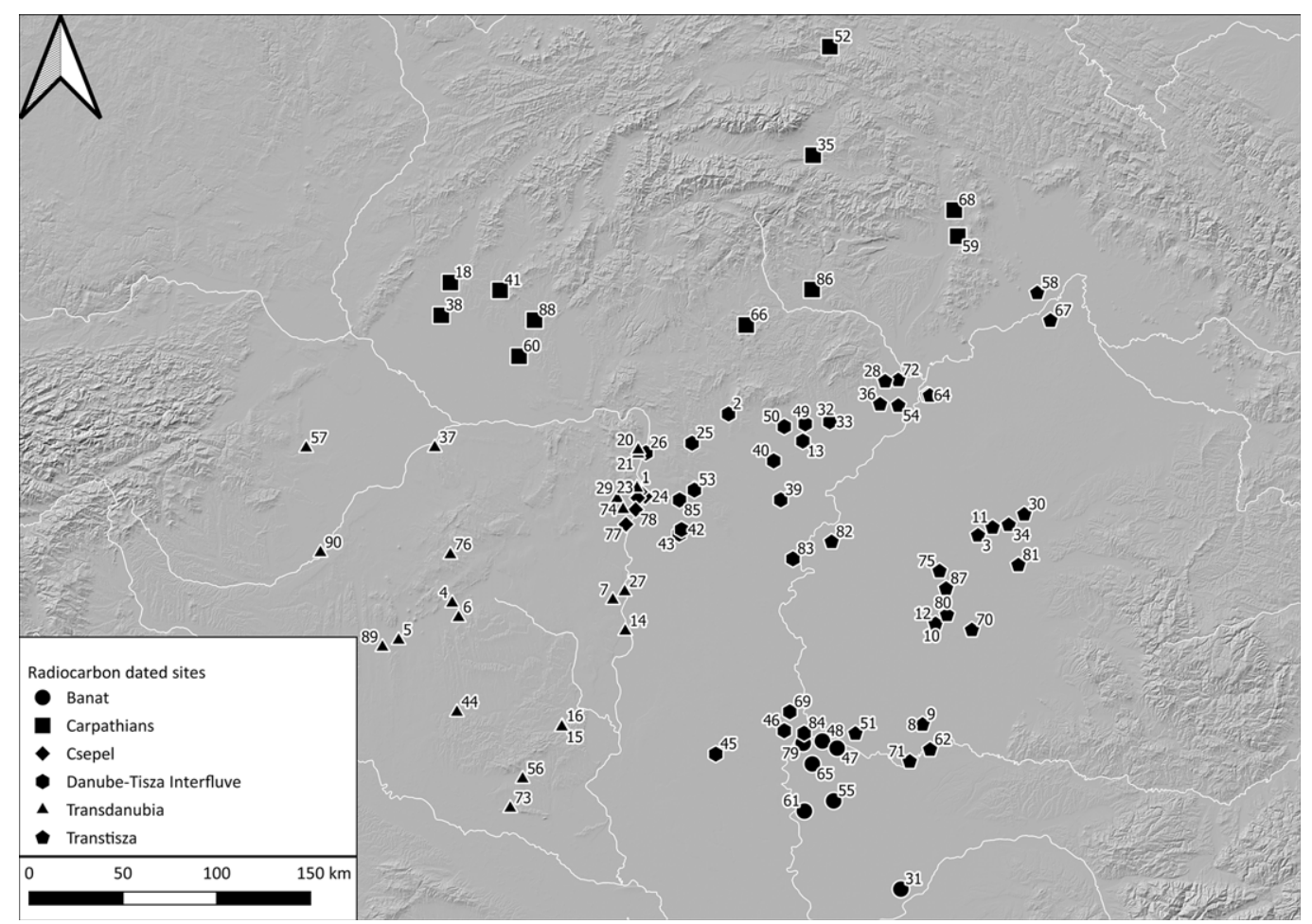

Figure 1 Spatial distribution of radiocarbon dates sites and the spatial groups.

The group classification allowed aggregating individual sites into meaningful categories, overcoming the over-representation of individual sites with a larger number of dates in the study, and shifting the focus towards recognizing spatial development in distinct regions.

The spatial groups were analyzed in terms of:

(1) contextual information on the dated samples,

(2) sample types used for the radiocarbon determination, and

(3) standard deviation of the radiocarbon determinations.

\section{Contextual Information}

Although information about site types were provided for the overwhelming majority of the collected dates $(97 \%, \mathrm{n}=495)$, the specific information on the dated context was significantly lower (Figure 2.1). The majority of reported contexts originate from burial features $(34.5 \%$, $\mathrm{n}=171)$, followed by unknown contexts $(27.3 \%, \mathrm{n}=135)$, settlement features $(25.5 \%, \mathrm{n}=126)$ and coring data, generally originating from settlement-related features $(12.9 \%, n=64)$.

Chronological sequences for specific regions were based on different proxies, with burial data representing the majority of the available determinations for the Banat group $(63.5 \%, n=47)$. Settlement-derived data was found prevalent for the Carpathians $(47.2 \%, n=42)$ and the 


\section{R Staniuk}

1)

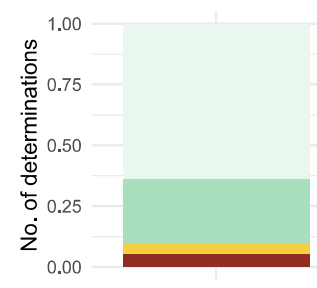

Banat

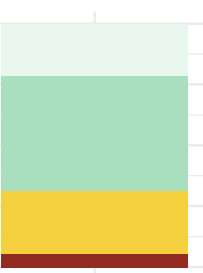

Carpathians

Contextual data [ $n=495]$

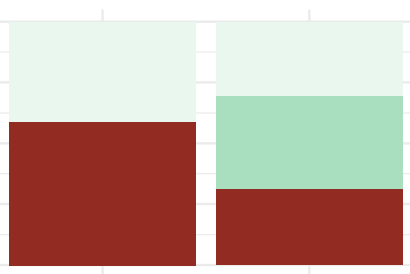

Csepel

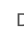
Site

Danube-Tisza Interfluve

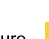

Coring

95]
2)

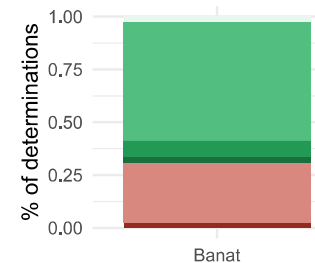

Banat

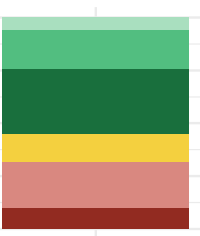

Carpathians

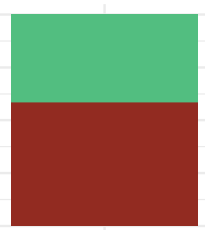

Csepel

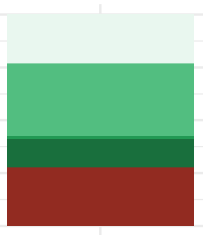

Danube-Tisza Interfluve Site type

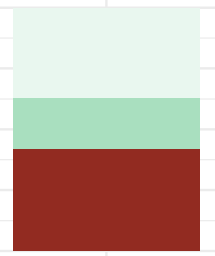

Transdanubia Unknown/Uncertain

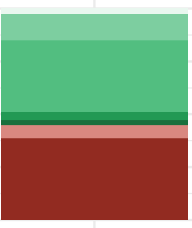

Transdanubia

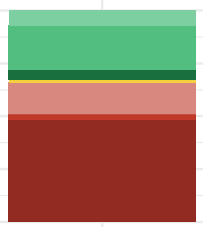

Transtisza

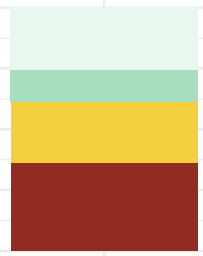

Transtisza

$$
\begin{array}{l|l|l|l|l|l}
\text { Animal bone } & \text { Bone } & \text { Human bone (?) } & \text { Wood } & \text { Charcoal or bone } \\
\hline \text { Animal bone (?) } & \text { Human bone } & \text { Seeds } & \text { Charcoal } & ?
\end{array}
$$

3)

14C standard deviation [ $n=495]$

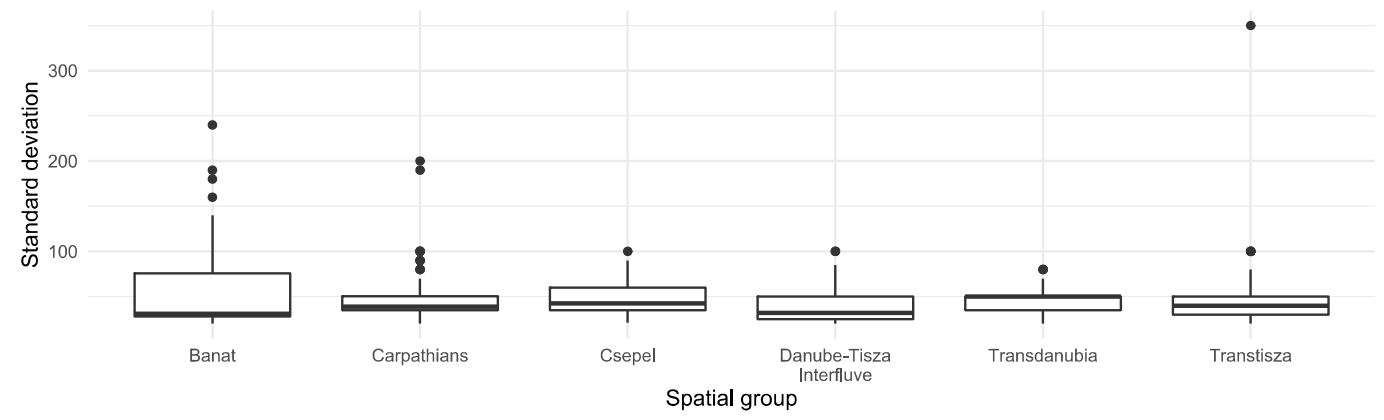

Figure 2 Evaluation of the radiocarbon determinations: (1) contextual information, (2) samples used for dating, (3) standard deviation of the reported ${ }^{14} \mathrm{C}$ dates.

Danube-Tisza Interfluve $(36 \%, \mathrm{n}=32)$. The remaining groups were generally characterized by the highest proportion of datings from unknown or uncertain contexts, with the largest proportion found in the Csepel group (59.1\%, $\mathrm{n}=13)$, followed by Transdanubia $(42.1 \%$, $\mathrm{n}=40)$, Transtisza $(36.2 \%, \mathrm{n}=46)$, and the Danube-Tisza Interfluve $(36.0 \%, \mathrm{n}=32)$.

\section{Sample Type}

Conclusive sample type information was provided for approximately $66,2 \%(n=328)$ of the collected samples (Figure 2.2). Ca. 3.8\% $(n=16)$ of samples were ambiguous in terms of their identification and were classified as possible animal $(n=5)$ or human bone $(n=11)$; in 3 cases the reported sample was classified either as charcoal or bone. 
The sample type information was reported for at least $75 \%$ of the cases in only 2 groups (Banat $[n=66]$, Carpathians [n=74]; cf. Figure 2.2). In the remaining groups, the defined sample information tended to vary from $70.7 \%$ (Danube-Tisza Interfluve $[n=63]$ ) to $40.9 \%$ (Csepel [n=9]).

Human bones represent the largest group of materials used for ${ }^{14} \mathrm{C}$ dating $(n=155)$, followed by unknown materials $(n=148)$ and charcoal $(n=65)$. This is specifically a problem for the dating of settlements, where samples of unknown materials or charcoal represent the majority of the available determinations. Without proper species identification and well-identified contexts or architectural structures, charcoal samples can result in erroneous dating of archaeological contexts (Bird 2013; Wright 2017). Without the information on the event leading to the formation of charcoal used for dating, the interpretation of the result cannot be directly translated into formulation of a coherent statement regarding the dated context. This is especially challenging for tell contexts, where the re-deposition of waste and sediment is directly responsible for site-formation processes (Miller Rosen 1986; Rosenstock 2009; Sørensen and Vicze 2013).

\section{Standard Deviation}

The distribution of standard deviations reported for radiocarbon measurements was analyzed for all available samples (Figure 2.3). The interquartile range of standard deviations is 30 to 50 years. When the data was classified according to spatial groups, similar median values were documented. These ranges represent different resolutions from a regional perspective with the highest resolution observed for the Banat (31), Danube-Tisza Interfluve (32), and Carpathians (38) groups. The Transtisza (40), Csepel (42.5), and Transdanubia (50) groups were characterized by a higher median. In nearly all cases outliers were observed. In the majority of cases, high standard deviation of radiocarbon determinations is related to the first wave of ${ }^{14} \mathrm{C}$ dating in the Carpathian Basin; high-resolution dating had not become prevalent until the second decade of the 21 st century (Figure 3).

\section{Selection of Radiocarbon Datings}

Based on the evaluation of the existing determinations it is possible to state that while site-based dates are available, the contextual information on the dated samples remains problematic, and

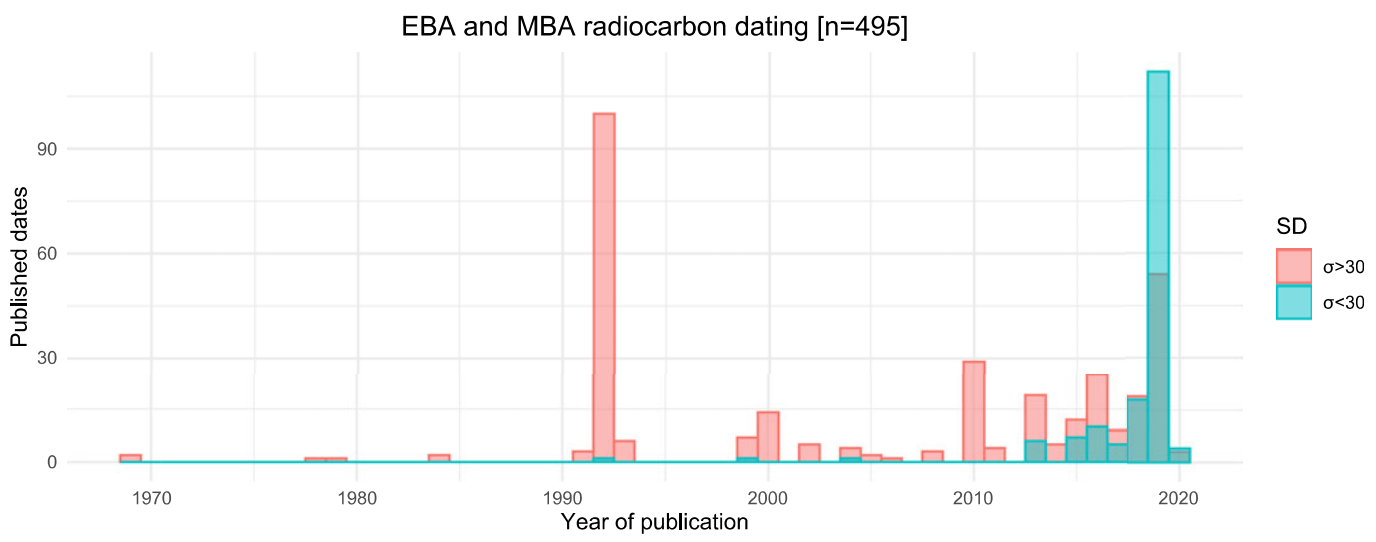

Figure 3 Radiocarbon dating in time and the changing accuracy of the radiocarbon determinations. 


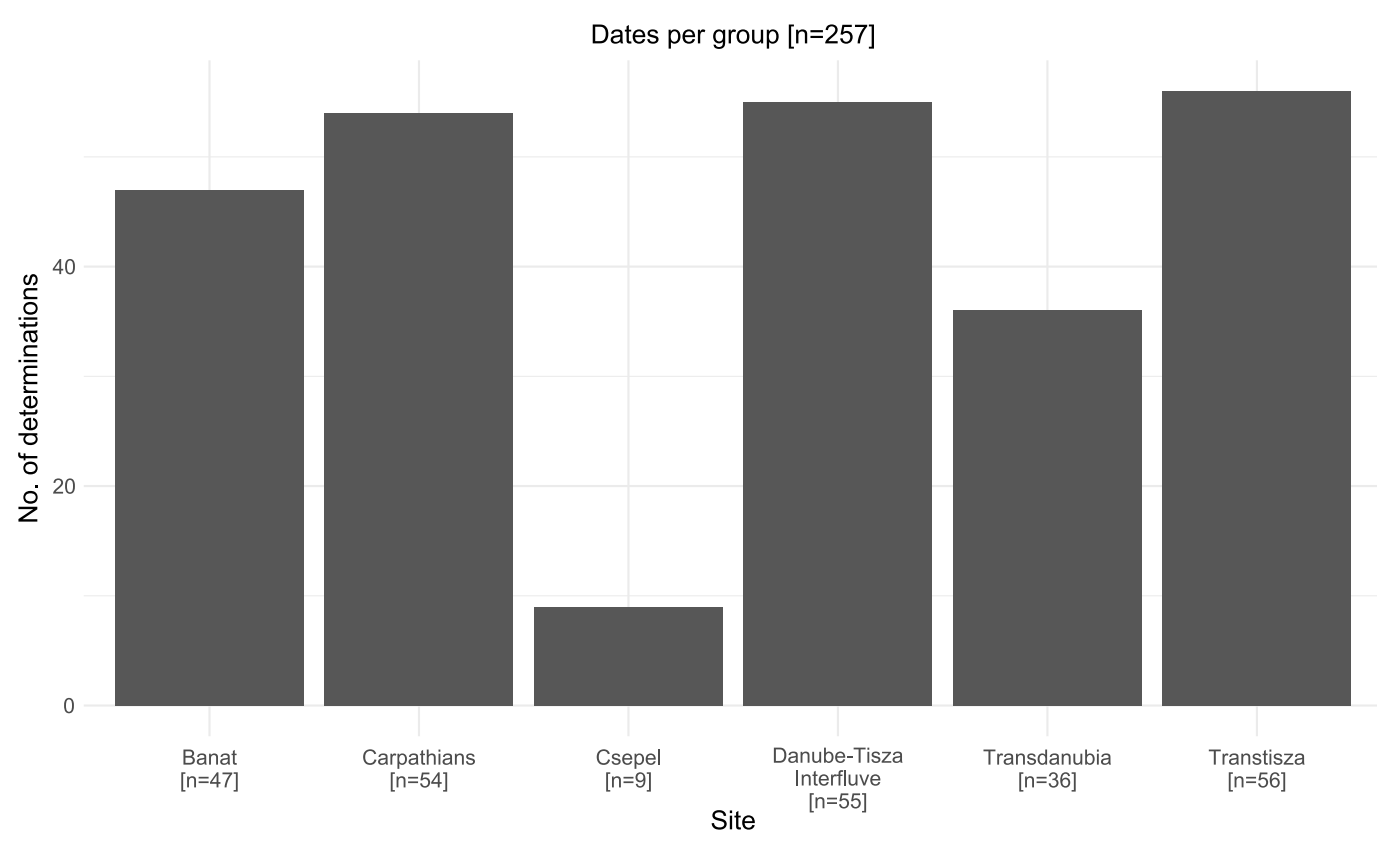

Figure 4 Selected radiocarbon determinations per spatial group.

the types of samples used for radiocarbon determinations were often unreported or collected from insufficiently described materials. While the standard deviation of the samples has been improved in the recent years by the availability of AMS-dating, the large number of preAMS dates affects the possibility of generating high-resolution models. The stated issues are related to the relatively large presence of legacy data linked to the early stage of implementing radiocarbon dating in archaeological practice. In addition, in some instances much older radiocarbon dates were present, usually related to oldest possible contexts, which greatly exceeded the general dating of the Bronze Age in the Carpathian Basin (e.g., Bln 4375 from Jelšovce). Therefore, in order to increase the quality of the following investigation, a selection was implemented and following groups of datings were removed from further analysis:

(1) radiocarbon dates without contextual information,

(2) determinations without information on the collected samples or originating from materials of unknown provenance,

(3) determinations with the standard deviation above 50, and

(4) calibrated radiocarbon samples older than $3000 \mathrm{BC}$.

As a result of the selection, the initial dataset was reduced to 257 dates. The distribution of dates across different groups became more similar, apart from the Csepel group (Figure 4). The initial number of sites was reduced to 39 , representing ca. $43 \%$ of the original dataset. Lastly, the distribution of site types under consideration changed, leading to the prevalence of determinations originating from cemeteries $(n=150)$ followed by settlements $(n=107)$. Taking into account the initial quantification, where settlements represented the largest number of determination $(n=311)$, the implemented selection reveals the problems of 
radiocarbon dating of settlement contexts in the Carpathian Basin: currently only ca. $34 \%$ of the available, settlement-derived dates are sufficient for high-quality determinations. The abundance of legacy data, while providing substantial information on the dating of particular sites, has to be considered as problematic for high-resolution investigations.

The selected dataset was modeled using KDE_Plot (Bronk Ramsey 2017) in Oxcal 4.4.3 (Bronk Ramsey 2009) using the IntCal20 calibration curve (Reimer et al. 2020). The function $K D E \_$Plot is used to summarize large datasets of radiocarbon and investigate the density of probability distribution, while removing the noise from the calibration curve (Bronk Ramsey 2017). In addition, the use of KDE plots allows consideration of realistic uncertainties in the temporal distribution of samples, therefore allowing evaluation whether the distinguished regions were characterized by similar probability distribution; this provides the means to consider whether the chronological sequence in the region suggests the contemporaneous emergence of large settlements and cemeteries (Bronk Ramsey 2017). Assuming that the KDE plots can be used to estimate the chronological position of human activities responsible for the formation of these dated samples, the KDE plots allow investigating the probability distribution of the activities taking place between the Early and Middle Bronze Age occupation in the Carpathian Basin.

Since in the majority of cases there is insufficient contextual data to group observations based on prior information, the emphasis is made on exploratory investigation of whether regional trajectories indicate the contemporaneity of human activity in the entire macroregion. Recently, the approach has been successfully and similarly used to compare the shift in burial practices in Central Europe (Brunner et al. 2021), as well as trace the spread of millet throughout Bronze Age Europe (Filipović et al. 2020).

\section{RESULTS}

Based on the available dataset the emergence of Bronze Age contexts in the Carpathian Basin can be positioned ca. $2600 \mathrm{cal} \mathrm{BC}$, with an increasing number of radiocarbon-dated contexts after ca. $2200 \mathrm{cal}$ BC (Figure 5). The curve developed for the entire Carpathian Basin indicates that the majority of Bronze Age contexts fall between 2200 and 1300 cal BC. The peak of probability distribution is found at ca. 1850 cal BC, marking the decreasing probability of radiocarbon dating until ca. $1600 \mathrm{cal} \mathrm{BC}$. Afterwards the probability distribution continues to decrease until ca. 1100 cal BC.

The Banat group is characterized by a relatively constrained probability distribution with the earliest contexts dating back to ca. $2200 \mathrm{cal} \mathrm{BC}$, followed by a steady increase until a peak at ca. $1700 \mathrm{cal} \mathrm{BC}$, followed by a final decline at ca. $1350 \mathrm{cal} \mathrm{BC}$. Based on the analysis, the dating of Bronze Age contexts in the region points towards a later onset of human activities than in the entire macro-region.

The Carpathians group is characterized by continuous dating of contexts related to the third millennium BC, followed by a peak at $1700 \mathrm{cal}$ BC and a final decline at ca. $1200 \mathrm{cal}$ BC. It seems probable to assume that the first peak occurred ca. 2100/2000 cal BC, and the current probability distribution represents the unequal sampling of dates from Bronze Age contexts.

The probability distribution of the Csepel group starts at ca. $2600 \mathrm{cal} \mathrm{BC}$, with the peak at ca. $2350 \mathrm{cal} \mathrm{BC}$, and a decline at ca. $2000 \mathrm{cal}$ BC. The dating indicates that human activities in the region were constrained with no post- $2000 \mathrm{cal} \mathrm{BC}$ occupation of the entire area. 


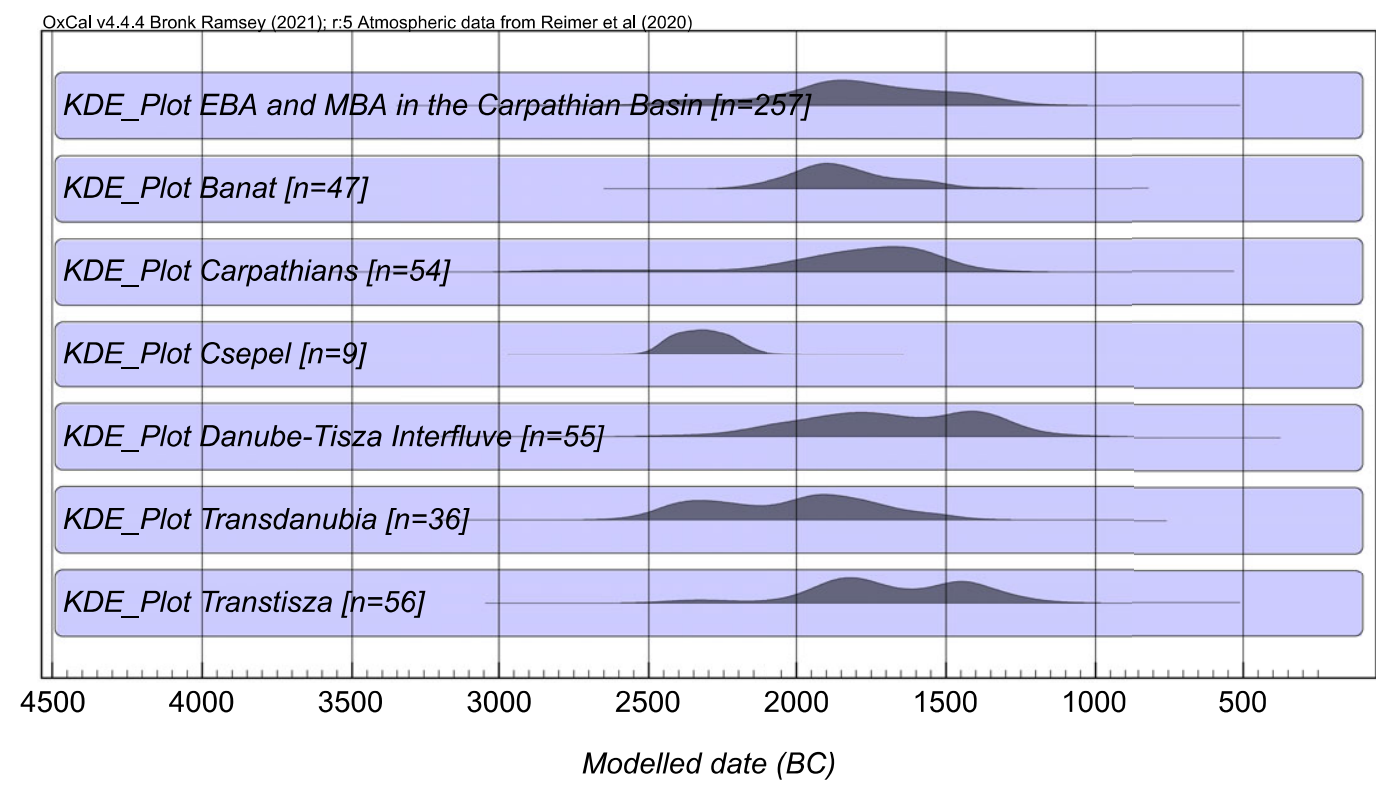

Figure 5 Early and Middle Bronze Age chronology of the Carpathian Basin: macroregional and regional perspectives (Supplementary Material 3).

The Danube-Tisza Interfluve group is characterized by an increase of probability distribution ca. $2500 \mathrm{cal}$ BC, a plateau between 1800 and $1500 \mathrm{cal} \mathrm{BC}$, and a decline ca. $900 \mathrm{cal}$ BC. The current dating suggests that the Bronze Age dating of the region focuses on the Middle Bronze Age period with evidence pointing towards long-term human presence throughout the entire second millennium BC.

The Transdanubia group is characterized by the earliest dating at 2650 cal BC, followed by a first peak at ca. $2350 \mathrm{BC}$, a decline until ca. $2150 \mathrm{cal} \mathrm{BC}$, second peak at $1900 \mathrm{cal} \mathrm{BC}$, and a final decrease at ca. $1400 \mathrm{cal} \mathrm{BC}$. As such it represents a chronological trajectory distinct from the macrocregional curve, both in terms of the onset and the final stage of Bronze Age contexts in the region.

The Transtisza group is characterized by an increase from ca. 2500 cal BC, first peak at ca. 2350 cal BC, first decline at 2150 cal BC, second peak at 1850 cal BC, second decline at 1600 cal BC, third peak at ca. 1450 cal BC, and the final decline at $1100 \mathrm{cal} \mathrm{BC}$. The probability distribution contrasts with the macroregional curve, since it is characterized by three instances of increasing probability of dating human activity.

Since the analyzed regional plots represent an aggregation of dates originating from different contexts, i.e., burials and settlements, determining the temporal position of different site types can help understand long-term habitation trends. Currently, the analyzed sample is characterized by the prevalence of burial data. This sampling bias affects the possibility of comparing regional chronologies in terms of the similarities between burial and settlement trajectories: the chronological record of only 3 groups comprises of dates originating from burials and settlements (Banat, Western Carpathians, Western Transdanubia). In some instances, the dated human remains originate from settlements, e.g., Kakucs-Balla domb (Danube-Tisza Interfluve), although it is not entirely clear whether new cultural practices 


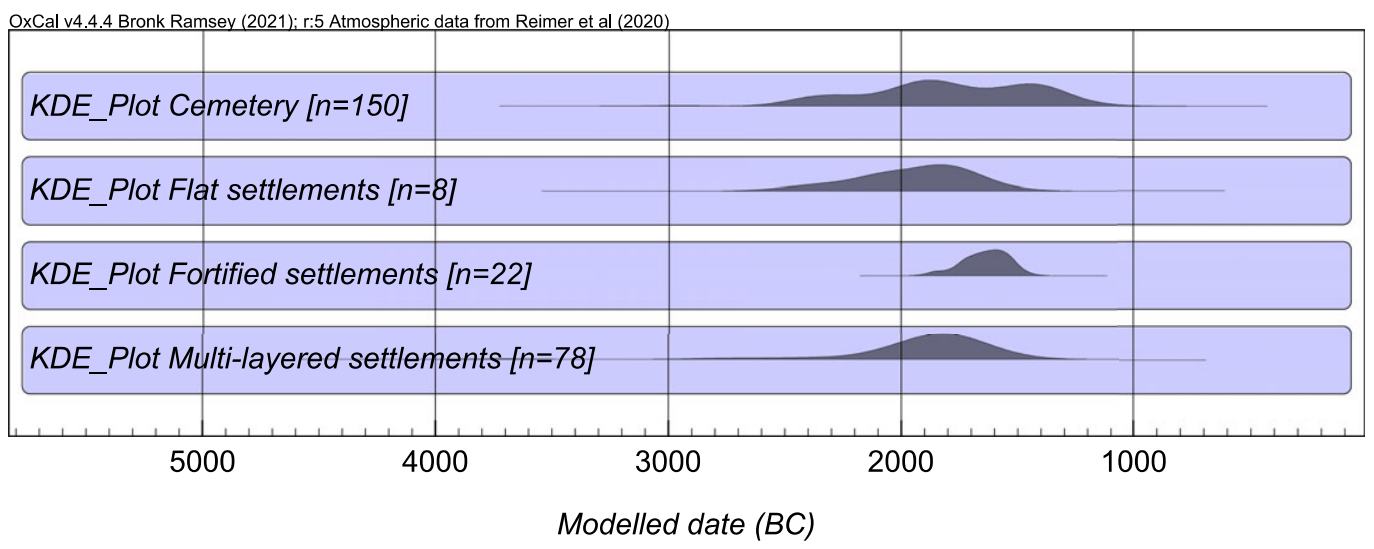

Figure 6 Settlement types and cemeteries in the Early and Middle Bronze Age Carpathian Basin: a radiocarbon model (Supplementary Material 4).

became incorporated as part of habitation practices, or the settlement was entirely repurposed as a burial ground (Jaeger and Kulcsár 2013). As such, the chronologies of the two types of the radiocarbon contexts will be evaluated as a whole in order to answer the question whether the temporal differences observed across the macroregional and regional groups can be linked to the different depositional processes.

Despite of the equalization of the Middle Bronze Age with the emergence of tell settlements, the first half of the second millennium BC was characterized by a diversity of habitation forms (Figure 6). The probability distribution of cemeteries, flat settlements, and multi-layered settlements overlaps until $2200 \mathrm{cal} \mathrm{BC}$ and the presence of flat settlements terminates ca. 1400 cal BC. The density of radiocarbon determinations from multi-layered settlements reaches its peak ca. $1800 \mathrm{cal} \mathrm{BC}$ and declines ca. $1400 \mathrm{cal} \mathrm{BC}$, similarly to the flat settlements. Between ca. 1800 and 1500 cal BC fortified settlements start to be documented. This category is generally applied for sites in Slovakia and southern Poland, which are characterized by material culture similar to Middle Bronze Age pottery of the FüzesabonyOtomani style (Jaeger 2016; Gancarski and Madej 2019). These sites are not treated as tells since in majority of cases only a single occupation layer was documented (Jaeger 2016). Finally, the Early and Middle Bronze Age funerary contexts point towards continued human presence from the second half of the third millennium cal $\mathrm{BC}$ until the end of the second millennium cal BC. The increasing density of radiocarbon dates in the burial record corresponds to the increasing diversity of settlement types ca. 2200 cal BC, when the first multi-layered settlements start to be documented.

The final stage of the analysis was determining the chronological position of specific sites within the context of the regional groups to determine whether the emergence of settlements was contemporary over the entire duration of the Early and Middle Bronze Age, and how was it related to the establishment of cemeteries. For the purpose of the analysis all sites with less than 2 radiocarbon measurements were removed from the analysis to ensure the representability of the KDE plots. This reduced the number of available sites to 26, and total number of available radiocarbon dates to 245 .

The Banat group comprised of three cemeteries and two settlements (Figure 7). The oldest flat settlement (Foeni Gaz) overlaps with the early stage of the multi-layered settlement 


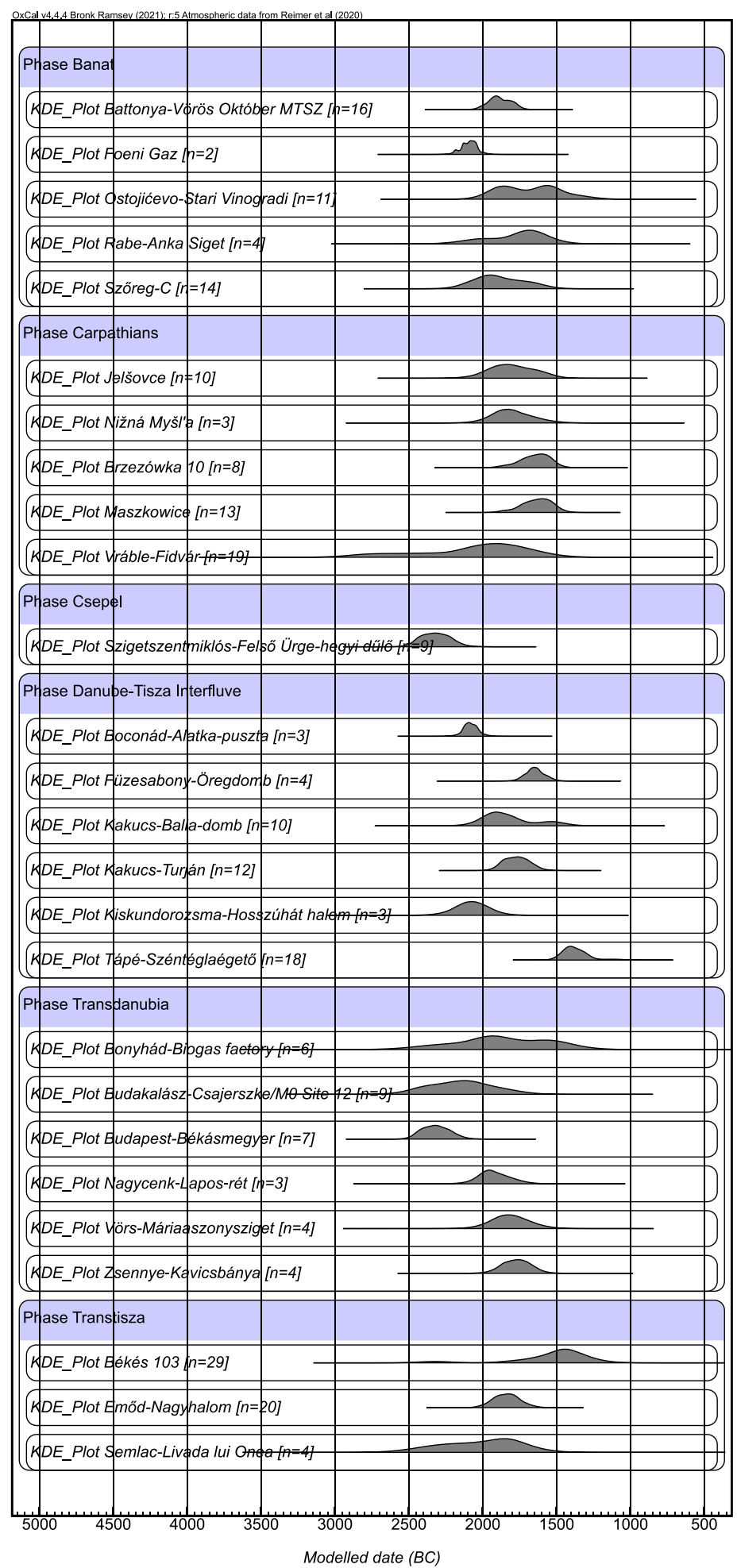

Figure 7 KDE plots for each of the archaeological sites within regional groups (Supplementary Material 5). 
(Rabe-Anka Siget), as well as the onset of three cemeteries. The probability distribution of the multi-layered settlement overlaps with all remaining cemeteries, with the Ostojićevo-Stari Vinogradi showing potential duration past the abandonment of the settlement.

The Carpathians group comprised of two cemeteries and three settlements. The multi-layered settlement of Vráble-Fidvár covers the entire timespan of the Early and Middle Bronze Age, where the transition between the flat and multi-layered settlement occurred ca. 2200 cal BC (Schlütz and Bittmann 2016). The cemeteries of Jelšovce and Nižna Myšl'a overlap with the probability distribution of Vráble-Fidvár, and partly with the two fortified settlements which emerged later (Brzezówka 10, Maszkowice).

The Csepel group represents the earliest context for human burials, prior to the establishment of any multi-layered settlements. In addition, no such forms of occupation are known from the island (Kulcsár 2011, 2013).

The Danube-Tisza Interfluve group comprised of four settlements and two cemeteries. The dated contexts originated from multi-layered phases of these settlements, indicating the overlap of this form of occupation with the earliest cemetery (Boconád-Alatka-puszta and Kiskundrozsma-Hosszúhat halom). The later settlements of Kakucs-Balla-domb, KakucsTurján, and Füzesabony-Öregdomb were all multi-layered settlements, which partly overlap. The cemetery of Tápé-Széntéglaégetô only partly overlaps with the tail of the probability distribution of Kakucs-Balla-domb.

The Transdanubia group comprised of five cemeteries and a single settlement. The cemetery of Bonyhád-Biogas factory was used throughout the entire Early and Middle Bronze Age. The remaining cemeteries have two probability distributions: from ca. $2500 \mathrm{cal} \mathrm{BC}$ to approx. 1500 cal BC, and ca. 2100 cal to 1500 cal BC. The settlement of Vörs-Máriaaszonysziget corresponds to the second one.

The Transtisza group comprised of a single cemetery and two settlements. While the cemetery of Békés was used already in the mid-third millennium cal BC, the majority of burials originate from the second half of the second millennium BC and continue past the 1500 cal BC threshold. The settlement on the other hand show the presence of long and short-term occupation, where the probability distribution of Semlac-Livada lui Onea points towards continued use from midthird millennium cal BC to 1500 cal BC. Emőd-Nagyhalom was used from 2000 to approx. 1600 cal BC.

\section{DISCUSSION}

The analysis indicates that while tell settlements can be generally positioned between 2200 $1250 \mathrm{cal} \mathrm{BC}$, their emergence was not uniform across all regional groups (Figure 8.1). This corresponds to the increasing formation of cemeteries in the region. In some groups (Carpathians, Transdanubia, Transtisza), this earliest phase of occupation is only characterized by burial contexts.

While onset of tells ca. 2200 cal BC marks the chronological thresholds for the majority of regional groups (Carpathians, Danube-Tisza Interfluve and Transtisza), the increasing number of settlements corresponds to ca. 1950 cal BC (Banat, Danube-Tisza Interfluve, Transtisza; Figure 8.2). The number of cemeteries increases regionally, although not all groups are immediately characterized by the establishment of burial grounds 


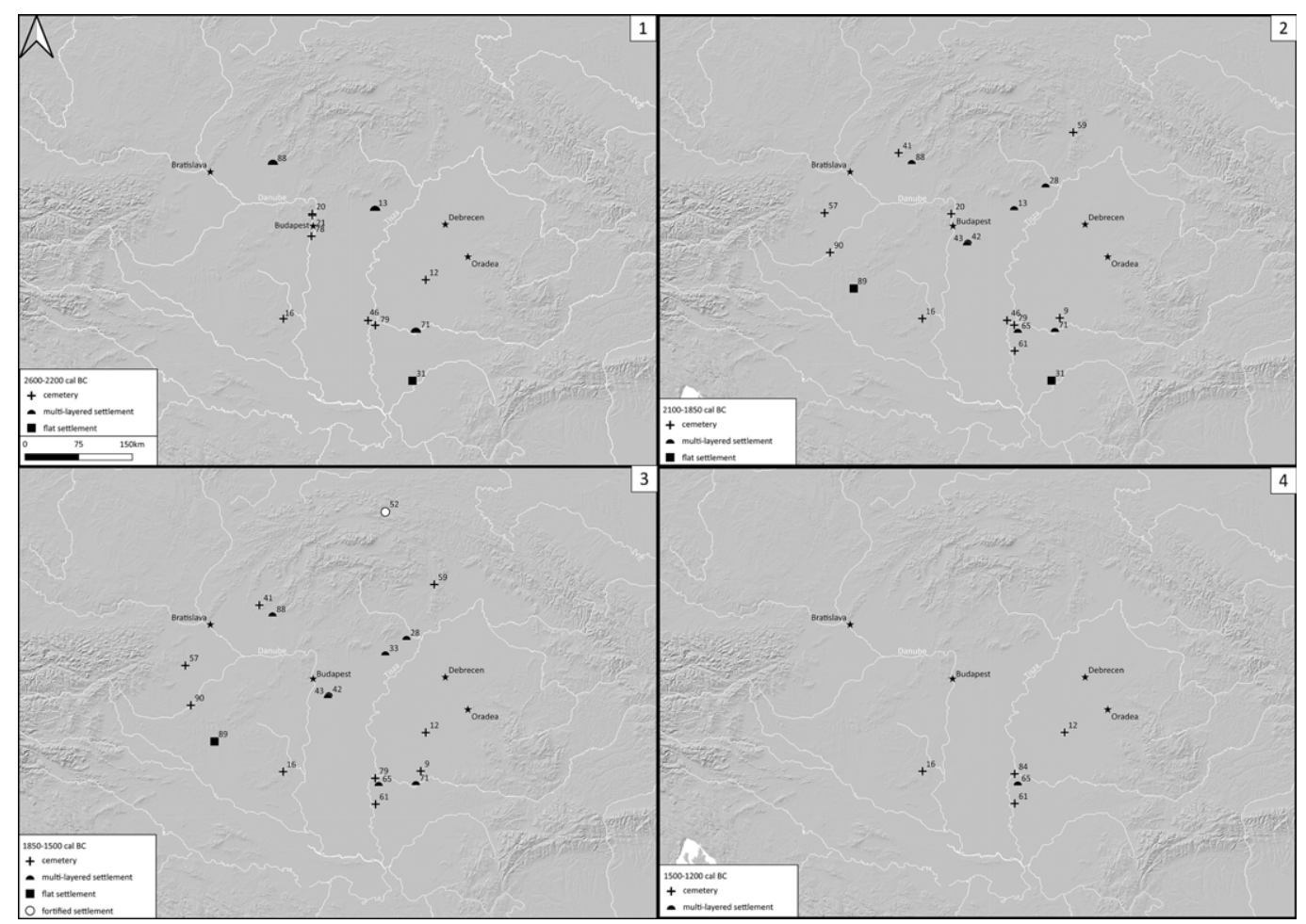

Figure 8 Radiocarbon-based model of spatial dynamics in the Carpathian Basin between 2600 and 1200 cal BC.

(Danube-Tisza-Interfluve). Although flat settlements were documented as well, even in areas where tell settlements become widespread, the current dating suggests that this habitation form became restricted to Transdanubia between 1850-1500 cal BC (Figure 8.3). This region specifically is characterized by a large number of contemporarily used cemeteries. The radiocarbon dataset for the majority of groups terminates ca. 1500 cal BC, with the majority of dating restricted to the Banat group (Figure 8.4).

The investigation shows that while there are substantial grounds to consider tells as a largely contemporary phenomenon, the formation of settlements was characterized by two different emergence trajectories. The initial stage was characterized by long-term occupation, which would result in the emergence of tell settlements (Carpathians, Danube-Tisza Interfluve, Transtisza). It is plausible that the maintenance of these eventually long-term settlements would establish a certain practice related to spatial management. After this initial longterm process, tell settlements would become more widespread, and generally were characterized by a shorter occupation. Similar trajectory is visible for the emergence of cemeteries, which were initially established in the mid-third millennium BC, followed by a secondary rise when the number of tell settlements increases. The study shows that there were similar regional trends of how people created their living environment, undergoing intensification due to a process of secondary aggregation in previously unoccupied areas. The challenge lies in determining how these findings fit into large, well-known sites which as of yet have not been subject to radiocarbon dating or could not be implemented in this model due to insufficient contextual data, e.g., Újhartyán-Vatya, Százhalombatta-Földvár, 
or Pecica "Şanţul Mare". It is probable that the emergence of chronologically early settlements was more widespread, but considering the current radiocarbon record of Early and Middle Bronze Age sites and especially the impact of legacy data, this points towards a viable hypothesis rather than a solution to the problem.

Two outliers were identified: the Csepel and Transdanubia groups, where no tell-based form of occupation was discovered. In the first case, a limited but rich dataset of a flat settlement and adjacent cemetery is known from excavations, although their exact temporal relationship cannot be determined using the proposed methodology (Patay 2013; Endrődi and Reményi 2016). Although the absence of Early and Middle Bronze Age tell settlements was observed early-on (Kiss 2012), the continued use of the cemetery in Bonyhád-Biogas factory would suggests that different means of establishing permanent spaces was taking place (Sørensen and Rebay-Salisbury 2008; Hajdu et al. 2016).

From the standpoint of on-going discussion regarding the collapse scenario explaining why a fairly large number of settlements were no longer occupied past ca. 1500 cal BC, no determinate answer can be provided (Fischl et al. 2013; Vicze et al. 2013; Duffy et al. 2019). The existing models indicate that the perspective of the so-called abandonment process was influenced by the sampling employed in different dating programs. The contextual data related to the final stages of occupation is scarce in terms of providing evidence of crises, conflict, and/or a dramatic turn of events which would contrast with the preceding phases (David 1998). This should be expected considering the long history of modern agriculture, where the position of tells overlaps with the most intensively used soils for agriculture (Staniuk 2020). Combined with the progressing erosion of elevated settlements, the problem of interpreting the final habitation stages requires the reconsideration of the research methodology and the selection of suitable datasets. This problem has already been documented for the site of Vráble-Fidvár, where settlement layers documented in 1967 were barely visible in 2009 (Bátora et al. 2012; Nowaczinski et al. 2013).

While the discontinuity of settlement use is supported by radiocarbon dating, currently the only potential correlational link to this process is the deposition of volcanic material leading to a climatic change ca. 1630 cal BC (Demény et al. 2019). While this points towards to a potential hazard, conducted investigation would suggest that occupation of settlements and the use of cemeteries continued for another hundred years. As such, another question remains whether decreasing temperature in the Carpathian Basin was immediately a challenge for the inhabitants of different sites, or whether it became a hazard only after a few generations.

\section{CONCLUSION}

The proposed model shows that the Early and Middle Bronze Age in the Carpathian Basin was characterized by the emergence of the first settlements ca. 2200 cal BC. This was accompanied by the emergence of the first cemeteries. This first stage of occupation would eventually result in the formation long-term settlements. Secondary occupation occurred ca. 1950 cal BC, again accompanied by the emergence of new cemeteries. The dated contexts suggest that ca. 1500 cal BC the majority of settlements were abandoned, and the only continued occupation could be documented in the Banat region. Despite the occurrence of a climatic change ca. $1600 \mathrm{cal} \mathrm{BC}$, sites continued to be used for approx. 100 years before being abandoned. 


\section{ACKNOWLEDGMENTS}

This work was supported by the $\mathrm{PhD}$ position "Tradition and Practice - Study on Pottery, Chronology and Social Dynamics of the Hungarian Bronze Age" (GSC608) at the Graduate School "Human Development in Landscapes" at the University of Kiel. I would like to thank John Meadows (Kiel) for his comments on the early draft of this paper, which helped me restructure my argument. Additional thanks go to Peter Barta (Bratislava) for access to his published work. I would also like to thank Sarah Martini (New Haven) for proof-reading the article and her comments. Lastly, I would like to thank both reviewers for their comments and suggestions on how to improve the paper.

\section{SUPPLEMENTARY MATERIAL}

To view supplementary material for this article, please visit https://doi.org/10.1017/RDC. 2021.83

\section{REFERENCES}

Barta P. 2001. Absolute dating of the Bronze Age in Slovakia: state of research. Anodos. Studies of the Ancient World 1:11-25.

Bátora J, Behrens A, Gresky J, Ivanova M, Rassmann K, Tóth P, Winkelmann K. 2012. The Rise and Decline of the Early Bronze Age Settlement Fidvár near Vráble, Slovakia. In: Kneisel J, Kirleis W, Dal Corso M, Taylor N, Tiedtke V, editors. Collapse or continuity? Environment and development of Bronze Age human landscapes. Proceedings of the International Workshop "Socio-Environmental Dynamics over the Last 12,000 Years: The Creation of Landscapes II (14th-18th March 2011)" in Kiel. Bonn: Dr. Rudolf Habelt. p. 111-129.

Bird MI. 2013. Charcoal. In: Elias SA, Mock CJ, editors. Encyclopedia of Quaternary science. 2nd edition. Amsterdam: Elsevier. p. 353-360. doi: 10.1016/B978-0-444-53643-3.00047-9.

Bóna I. 1963. The cemeteries of the Nagyrév culture. Alba Regia 2-3:11-23.

Bóna I. 1975. Die mittlere Bronzezeit Ungarns und ihre südöstlichen Beziehungen. Budapest: Akadémiai Kiadó.

Bóna I. 1992. Bronzezeitliche Tell-Kulturen in Ungarn. In: Meier-Arendt W, editor. Bronzezeit in Ungarn: Forschungen in Tell-Siedlungen an Donau und Theiss. Frankfurt am Main: Stadt Frankfurt am Main. p. 9-41.

Bronk Ramsey C. 2009. Bayesian analysis of radiocarbon dates. Radiocarbon 51(1):337-360. doi: 10.2458/azu_js_rc.v51i1.3494.

Bronk Ramsey C. 2017. Methods for summarizing radiocarbon datasets. Radiocarbon 59(6):18091833. doi: 10.1017/RDC.2017.108.

Brunner M, von Felten J, Hinz M, Hafner A. 2021. Central European Early Bronze Age chronology revisited: a Bayesian examination of large-scale radiocarbon dating. PLOS ONE 15(12):1-24. doi: 10.1371/journal.pone.0243719.
Czene A. 2017. The Position of the Bell BeakerCsepel Group at Budakalász. In: Kulcsár G, Szabó GV, Kiss V, Váczi G, editors. State of the Hungarian Bronze Age research. Proceedings of the conference held between 17th and 18th of December 2014. Budapest: Institute of Archaeology, Research Centre for the Humanities, Hungarian Academy of Sciences, Institute of Archaeological Sciences, Faculty of Humanities, Eötvös Loránd University. p. 179-199.

David W. 1998. Zum Ende der bronzezeitlichen Tellsiedlungen im Karpatenbecken. In: Küster $\mathrm{H}$, Lang A, Schauer P, editors. Archäologische Forschungen in Urgeschichtlichen Siedlungslandschaften. Festschrift für Georg Kossack zum 75. Geburtstag. Bonn: Dr. Rudolf Habelt GmbH. p. 231-267.

Demény A, Kern Z, Czuppon G, Németh A, SchöllBarna G, Siklósy Z, Leél-『ssy Sz, Cook G, Serlegi G, Bajnóczi B, Sümegi P, Király A, Kiss V, Kulcsár G, Bondár M. 2019. Middle Bronze Age humidity and temperature variations, and societal changes in East-Central Europe. Quaternary International 504(10):80-95. doi: 10. 1016/j.quaint.2017.11.023.

Duffy PR, Parditka GyM, Giblin JI, Paja L. 2019. The problem with tells: lessons learned from absolute dating of Bronze Age mortuary ceramics in Hungary. Antiquity 93(367):63-79. doi: 10.15184/aqy.2018.179.

Earle T, Kristiansen K. 2010. Introduction: theory and practice in the late Prehistory of Europe. In: Earle T, Kristiansen K, editors. Organizing Bronze Age societies: the Mediterranean, Central Europe, and Scandinavia compared. New York: Cambridge University Press. p. 1-33.

Endrődi A, Reményi L. 2016. A Bell Beaker settlement in Albertfalva, Hungary (2470-1950 BC). Budapest: Budapest History Museum. 
Filipović D, Meadows J, Corso MD, Kirleis W, Alsleben A, Akeret Ö, Bittmann F, Bosi G, Ciută B, Dreslerová D, Effenberger H, Gyulai F, Heiss AG, Hellmund M, Jahns S, Jakobitsch T, Kapcia M, Klooß S, Kohler-Schneider M, Kroll H, Makarowicz P, Marinova E, Märkle T, Medović A, Mercuri A-M, Mueller-Bieniek A, Nisbet R, Pashkevich G, Perego R, Pokorný P, Pospieszny Ł, Przybyła M, Reed K, Rennwanz J, Stika H-P, Stobbe A, Tolar T, Wasylikowa K, Wiethold J, Zerl T. 2020. New AMS ${ }^{14} \mathrm{C}$ dates track the arrival and spread of broomcorn millet cultivation and agricultural change in prehistoric Europe. Scientific Reports 10(1):13698. doi: 10. 1038/s41598-020-70495-Z.

Fischl KP, Kiss V, Kulcsár G, Szeverényi V. 2013. Transformations in the Carpathian Basin around 1600 B.C. In: Meller H, Bertemes F, Bork H-R, Risch R, editors. 1600-Kultureller Umbruch im schatten des Thera-Ausbruchs? 4. Mitteldeutscher Archäologentag vom 14. bis 16 . Oktober 2011 in Halle (Saale). Halle (Saale): Landesamt für Denkmalpflege und Archäologie Sachsen-Anhalt. p. 355-371.

Fischl KP, Kiss V, Kulcsár G, Szeverényi V. 2015. Old and new narratives for Hungary around 2200 BC. In: Meller H, Arz HW, Jung R, Risch R, editors. $2200 \mathrm{BC}$-Ein Klimasturz als Ursache für den Zerfall der Alten Welt? 7. Mitteldeutscher Archäologentag vom 23. Bis 26. Oktober 2014 in Halle (Saale). Halle (Saale): Landesamt für Denkmalpflege und Archäologie Sachsen-Anhalt. p. 503-523.

Forenbaher S. 1993. Radiocarbon dates and absolute chronology of the central European Early Bronze Age. Antiquity 67(255):218-256. doi: 10.1017/ S0003598X00045336.

Gancarski J, Madej P. 2019. Defensive Settlements of the Otomani-Füzesabony Culture in the Wisłoka River Basin. In: Fischl KP, Kienlin TL, editors. Beyond divides - the Otomani-Füzesabony phenomenon. Current approaches to settlement and burial in the North-eastern Carpathian basin and adjacent areas. Bonn: Dr. Rudolf Habelt GmbH. p. 33-46.

Gogâltan F. 1999. Bronzul timpuriu şi mijlociu în Banatul românesc şi pe cursul inferior al Mureşului. Cronologia şi descoperirile de metal. Timişoara: Editura Orizonturi Universitate Timişoara.

Gogâltan F. 2017. The Bronze Age Multilayered Settlements in the Carpathian Basin (ca. 2500 1600/1500 BC). An old catalogue and some chronological problems. Journal of Ancient History and Archaeology 4(3):28-55.

Gömöri J, Melis E, Kiss V. 2018. A cemetery of the Gáta-Wieselburg culture at Nagycenk (Western Hungary). Acta Archaeologica Academiae Scientiarum Hungaricae 69:5-82. doi: 10.1556/ 072.2018.69.1.1.
Hajdu T, György-Toronyi A, Pap I, Rosendahl W, Szabó G. 2016. The chronology and meaning of the Transdanubian encrusted pottery decoration. Prahistorische Zeitschrift 91(2):353-368. doi: 10.1515/pz-2016-0024.

Jaeger M. 2016. Bronze Age fortified settlements in Central Europe. Bonn-Poznań: Wydawnictwo Nauka i Innowacje.

Jaeger M, Kulcsár G. 2013. Kakucs-Balla-domb. A case study in the absolute and relative chronology of the Vatya culture. Acta Archaeologica Academiae Scientiarum Hungaricae 64(2):289-320. doi: 10.1556/AArch.64.2013.2.2.

Kalicz N. 1968. Die Frühbronzezeit in NordostUngarn. Budapest: Akadémiai Kiadó.

Kalicz N. 1982. Die terminologischen und chronologischen Probleme der Kupfer- und Bronzezeit in Ungarn. In: Aspes A, editor. Il passaggio dal neolitico all'età del bronzo nell'Europa centrale e nella regione alpina. Problemi cronologici e terminologici. Atti del X Simposio internazionale sulla fine del neolitico e gli inizi dell'età del bronzo in Europa, Lazise, Verona 8-12 aprile 1980. Verona: Museo Civico di Storia Naturale. p. 117-137.

Kalicz-Schreiber R. 2010. Ein Gräberfeld der Spätbronzezeit von Budapest-Békásmegyer. Budapest: L'Harmattan.

Kienlin TL. 2015. Bronze Age tell communities in context. An exploration into culture, society, and the study of European prehistory. Part 1. Oxford: Archaeopress Archaeology.

Kiss V. 2012. Middle Bronze Age encrusted pottery in western Hungary. Budapest: Archaeolingua.

Kovács T. 1977. Die Bronzezeit in Ungarn. Budapest: Corvina Verlag.

Kristiansen K, Larsson TB. 2005. The rise of the Bronze Age society. Travels, transmissions and transformations. Cambridge: Cambridge University Press.

Kulcsár G. 2009. The beginnings of the Bronze Age in the Carpathian Basin. The Makó-Kosihy-Čaka and the Somogyvár-Vinkovci cultures in Hungary. Budapest: Archaeolingua.

Kulcsár G. 2011. Untangling the Early Bronze Age in the Middle Danube Valley. In: Kovacs G, Kulcsár G, editors. Ten thousand years along the Danube. Budapest: Archaeolingua. p. 179-210.

Kulcsár G. 2013. Glimpses of the third millennium $\mathrm{BC}$ in the Carpathian Basin. In: Anders A, Kulcsár G, Kalla G, Kiss V, Szabó GV, editors. Moments in time. Papers presented to Pál Raczky on his 60th birthday. Budapest: L'Harmattan. p. 643-659.

Marková K, Ilon G. 2013. Slovakia and Hungary. In: Fokkens H, Harding A, editors. The Oxford handbook of the European Bronze Age. Oxford: Oxford University Press. p. 813-836.

Máthé MSz. 1984. Preliminary report on the 1977 1982 excavations at the Neolithic and Bronze 
Age settlement in Berettyóújfalu-Herpály. Part II: Bronze Age. Acta Archaeologica Academiae Scientiarum Hungaricae 36:137-159.

Máthé MSz. 1992. Bakonszeg-Kádárdomb. In: Meier-Arendt W, editor. Bronzezeit in Ungarn: Forschungen in Tell-Siedlungen an Donau und Theiss. Frankfurt am Main: Stadt Frankfurt am Main. p. 166-167.

Michelaki K. 2008. Making pots and potters in the Bronze Age Maros Villages of Kiszombor-ÚjÉlet and Klárafalva-Hajdova. Cambridge Archaeological Journal 18(3):355-380. doi: 10. 1017/S0959774308000413.

Miller Rosen A. 1986. Cities of Clay. The Geoarchaeology of Tells. Chicago and London: The University of Chicago Press.

Nowaczinski E, Schukraft G, Rassmann K, Hecht S, Texier F, Eitel B, Bubenzer O. 2013. GeophysicalGeochemical Reconstruction of Ancient Population Size - the Early Bronze Age settlement of Fidvár (Slovakia). Archaeological Prospection 20:267-283. doi: 10.1002/arp.1460.

O'Shea JM. 1992. A radiocarbon-based chronology for the Maros Group of southeast Hungary. Antiquity 66(250):97-102. doi: 10.1017/ S0003598X00081084.

O'Shea JM, Parditka Gy, Nicodemus A, Kristiansen K, Sjögren K-G, Paja L, Pálfi Gy, Milašinović L. 2019. Social formation and collapse in the TiszaMaros region: Dating the Maros Group and its Late Bronze Age successors. Antiquity 93(369): 604-623. doi: 10.15184/aqy.2019.40.

Patay R. 2013. Bell Beaker cemetery and settlement at Szigetszentmiklós: first results. In: Heyd V, Kulcsár G, Szeverényi V, editors. Transitions to the Bronze Age. Interregional interaction and socio-cultural change in the third millennium $\mathrm{BC}$ Carpathian Basin and neighbouring regions. Budapest: Archaeolingua. p. 287-317.

Poroszlai I. 1992. Bölcske-Vörösgyúrû (Vörösgyír). In: Meier-Arendt W, editor. Bronzezeit in Ungarn: Forschungen in Tell-Siedlungen an Donau und Theiss. Frankfurt am Main: Stadt Frankfurt am Main. p. 141-145.

Przybyła MS. 2009. Intercultural contacts in the Western Carpathian area at the turn of the 2nd and 1st millennia BC. Warszawa: Narodowe Centrum Kultury.

Raczky P, Hertelendi E, Horváth F. 1992. Zur Absoluten Datierung der bronzezeitlichen Tellkulturen in Ungarn. In: Meier-Arendt W, editor. Bronzezeit in Ungarn: Forschungen in TellSiedlungen an Donau und Theiss. Frankfurt am Main: Stadt Frankfurt am Main. p. 42-45.

Reimer PJ, Austin WEN, Bard E, Bayliss A, Blackwell PG, Bronk Ramsey C, Butzin M, Cheng H, Edwards RL, Friedrich M, Grootes PM, Guilderson TP, Hajdas I, Heaton TJ, Hogg AG, Hughen KA, Kromer B, Manning SW, Muscheler R, Palmer JG, Pearson C, van der
Plicht J, Reimer RW, Richards DA, Scott EM, Southon JR, Turney CSM, Wacker L, Adolphi F, Büntgen U, Capano M, Fahrni SM, Fogtmann-Schulz A, Friedrich R, Köhler P, Kudsk S, Miyake F, Olsen J, Reinig F, Sakamoto M, Sookdeo A, Talamo S. 2020. The IntCal20 Northern Hemisphere radiocarbon age calibration curve $(0-55$ cal kBP). Radiocarbon 62(4):725-757.

Rosenstock E. 2009. Tells in Südwestasien und Südosteuropa. Remshalden: Verlag Bernhard Albert Greiner.

Schlütz F, Bittmann F. 2016. Dating archaeological cultures by their moats? A case study from the Early Bronze Age settlement Fidvár near Vráble, SW Slovakia. Radiocarbon 58(2):331343. doi: 10.1017/RDC.2015.17.

Sørensen MLS, Rebay-Salisbury K. 2008. Landscapes of the body: burials of the Middle Bronze Age in Hungary. European Journal of Archaeology 11(1):49-74. doi: 10.1177/ 1461957108101241.

Sørensen MLS, Vicze M. 2013. Locating household activities on a Bronze Age tell. In: Madela M, Kovács G, Berzsenyi B, Briz i Godino I, editors. The archaeology of household. Oxford: Oxbow Books. p. 159-178.

Stanczik I, Tárnoki J. 1992. JászdózsaKápolnahalom. In: Meier-Arendt W, editor. Bronzezeit in Ungarn: Forschungen in TellSiedlungen an Donau und Theiss. Frankfurt am Main: Stadt Frankfurt am Main. p. 120-127.

Staniuk R. 2020. Tradition and Practice. Study on pottery, chronology and social dynamic of the Hungarian Bronze Age. Bonn: Dr. Rudolf Habelt GmbH.

Staniuk R, Jaeger M, Kulcsár G, Taylor N, Niebieszczański J, Müller J. 2020. Moving bottom-up: the case study of Kakucs-Turján (Hungary) and its implications for studies of multi-layered Bronze Age settlements in the Carpathian Basin. In: Blanco-González A, Kienlin TL, editors. Current approaches to tells in the prehistoric Old World. Oxford and Oakville: Oxbow Books. p. 57-72.

Vicze M. 2011. Bronze Age cemetery at DunaújvárosDuna-dúlő. Budapest: Eötvös Loránd University, Institute of Archaeological Sciences.

Vicze M, Poroszlai I, Sümegi P. 2013. Koszider: hoard, phase, period? Round table conference on the Koszider problem. Százhalombatta: Matrica Museum.

Visy Z. 2003. Hungarian archaeology at the turn of the millennium. Budapest: Ministry of National Cultural Heritage.

Wright DK. 2017. Accuracy vs. precision: understanding potential errors from radiocarbon dating on African landscapes. African Archaeological Review 34(3):303-319. doi: 10. 1007/s10437-017-9257-z. 